\title{
KAJIAN KETAHANAN PANGAN RUMAH TANGGA PETANI PENGGARAP TEH
}

\author{
Y. Samantha ${ }^{1 \mathrm{a}}$, NS. Menganti ${ }^{1}$, L. Amaliah ${ }^{1}$ \\ ${ }^{a}$ Staf Pengajar/Peneliti Jurusan Agribisnis Fakultas Pertanian, Universitas Winaya Mukti \\ Jl Raya Tanjungsari - Sumendang , 45362 \\ ${ }^{a}$ Korespondensi: Yuliana Samantha; Email : yuliana.faperta@gmail.com
}

\begin{abstract}
ABSTRAK
Tantangan pembangunan pertanian Indonesia antara lain bagaimana memenuhi kebutuhan pangan serta keseimbangan gizi keluarga. Ketahanan pangan minimal mengandung tiga unsur pokok "ketersediaan, distribusi, dan konsumsi pangan". Sampel penelitian adalah keluarga yang bekerja sebagai petani penggarap teh dan tergabung dalam Kelompok Tani Sabeulit berjumlah 12 orang dengan menggunakan metode stratified random sampling atau sampel acak sederhana terstrata. Strata didasarkan pada luas lahan yang digarap oleh petani. Hasil penelitian menunjukkan bahwa karakteristik petani sampel semua strata rata-rata berumur 51 tahun. Rata-rata pendidikan formal kepala keluarga adalah lulusan sekolah dasar (SD). Ketersediaan beras rumah tangga petani yang paling besar adalah strata lahan sedang kemudian diikuti oleh strata lahan luas, selanjutnya yang paling sedikit ketersediaan berasnya adalah rumah tangga strata lahan sempit. Rumah tangga petani penggarap dikategorikan kurang kontinyu $23,1 \%$, dan $76,9 \%$ dinyatakan kontinyu stabilitas dan aksesbilitas ketahanan pangan komoditas beras. Proporsi rumah tangga petani yang tergolong tahan pangan 58.3\%, rawan pangan $25 \%$ dan tidak tahan pangan $16.7 \%$ dari keseluruhan petani sampel. Implikasi indikator kajian ketahanan sebagai gambaran bagi pemangku kebijakan khususnya dan pengetahuan bagi masyarakat sebagai bagian dari permasalahan yang dihadapi oleh manusia dalam pemenuhan kebutuhan pokok. Ketahanan pangan diukur berdasarkan aksesbilitas, ketersedian dan konsumsi berdasarkan pengeluaran rumah tangga terhadap pangan dan non pangan.
\end{abstract}

Kata kunci: Petani, Teh, Ketahanan Pangan, Pangan 


\section{PENDAHULUAN}

Tantangan pembangunan pertanian Indonesia antara lain bagaimana memenuhi kebutuhan pangan serta keseimbangan gizi keluarga. Beberapa ahli sepakat bahwa ketahanan pangan minimal mengandung tiga unsur pokok yaitu "ketersediaan, distribusi, dan konsumsi pangan",Unsur distribusi dan konsumsi merupakan penjabaran dari aksessibilitas masyarakat terhadap pangan". Bila salah satu unsur tersebut tidak dipenuhi maka suatu negara belum dapat dikatakan mempunyai ketahanan pangan yang baik. Walaupun pangan tersedia cukup di tingkat nasional dan regional, tetapi jika akses individu untuk memenuhi kebutuhan pangannya tidak merata, maka ketahanan pangan masih dikatakan rapuh. Akses terhadap pangan, ketersediaan pangan dan risiko terhadap akses dan ketersediaan pangan tersebut merupakan determinan yang esensial dalam ketahanan pangan.

Pada Perkebunan rakyat, areal yang diusahakan kecil-kecil tetapi jumlahnya banyak. Petani penggarap (penyakap) adalah petani yang menguasai usahanya karena adanya sewa ataupun karena bagi hasil sesuai dengan perjanjian yang telah disepakati. Desa Citengah di Sumedang Selatan dikenal sebagai tempat agrowisata perkebunan teh rakyat. Sebagian besar masyarakat bermata pencaharian sebagai petani penggarap teh di perkebunan teh rakyat. Sehubungan dengan paparan di atas maka penelitian mengenai Kajian Ketahanan Pangan Rumah Tangga Petani Penggarap Teh di Perkebunan Rakyat di Desa Citengah, Kecamatan Sumedang Selatan, Kabupaten Sumedang ini bertujuan untuk mengetahui kondisi ketahanan pangan rumah tangga petani penggarap teh.

\section{BAHAN DAN METODE}

Ketahanan pangan bertambah penting lagi terutama sejak Indonesia tidak menjadi salah satu anggota Organisasi Perdagangan Dunia (WTO). Artinya, di satu pihak, pemerintah harus memperhatikan kelangsungan produksi pangan di dalam negeri demi menjamin ketahanan pangan, namun dipihak lain, Indonesia tidak bisa menghambat impor pangan dari luar. Dengan kata lain, apabila Indonesia tidak siap di dalam WTO bisa membuat Indonesia menjadi sangat tergantung pada impor pangan, dan dapat mengancam ketahanan pangan di dalam negeri. (Tambunan 2010).

$$
\text { Menurut Fajria dkk (2016) }
$$

berdasarkan definisi ketahanan pangan dari Food and Agricultural Organization (FAO) (1996) dan UU No 7 Tahun 1996, terdapat empat komponen yang harus dipenuhi untuk mencapai kondisi ketahanan pangan, yaitu: (a). Kecukupan ketersediaan pangan, (b). Stabilitas ketersediaan pangan tanpa fluktuasi dari musim ke musim atau dari tahun ke tahun, (c). Aksesibilitas/ keterjangkauan terhadap pangan, (d). Kualitas/ keamanan pangan. Keempat komponen tersebut digunakan untuk mengukur ketahanan pangan di tingkat rumah tangga. Keempat indikator tersebut merupakan indikator utama untuk mendapatkan indeks ketahanan pangan.

Metode penelitian menggunakan metode stratified random sampling. Dasar penentuan jumlah sampel dilakukan dengan menggunakan rumus Slovin (Setiawan 2007), yaitu sebagai berikut :

$$
\mathrm{n}=\frac{\mathrm{N}}{1+\mathrm{N}(\mathrm{e})^{2}}
$$

Dikeahui :

$\mathrm{n}=$ Jumlah sampel

$\mathrm{N}=$ Ukuran populasi

$\mathrm{E}=$ Batas kekeliruan (bound of error) yang dikehendaki tidak lebih dari 5\%;10\%; $15 \%$

\section{HASIL DAN PEMBAHASAN}

Jika dibandingan antar strata, tampak tidak ada konsistensi hubungan antara kategori luas lahan dengan jumlah tanggungan rumah tangga. Namun jika diperhatikan, komposisi anggota rumah tangga usia produktif terlihat lebih banyak pada rumah tangga berlahan sedang. Untuk 
jumlah anggota rumah tangga usia produktif dapat dijadikan ukuran potensi ketersediaan tenaga kerja dalam keluarga. Jika dilihat angka-angka pada Tabel 1, maka disimpulkan semakin tinggi strata rumah tangga petani tidak menjamin rata- rata potensi tenaga kerja keluarga juga semakin besar.

Tabel 1 Karakteristik Demografi Rumah Tangga Petani Penggarap Lahan Teh menurut Strata Lahan (Rata-rata)

\begin{tabular}{lcccc}
\hline \multicolumn{1}{c}{ Karakteristik } & Lahan & Lahan & Lahan & Total \\
& Sempit & Sedang & Luas & (thn) \\
Umur KK (th) & 63,7 & 43,3 & 55,7 & 51,5 \\
Pendidikan formal KK (thn) & 6 & 8 & 6 & 7 \\
Pendidikan Nonformal KK (thn) SLPHT & 3 & 9 & 6 & 3 \\
Pendidikan formal ART Pria (thn) & 6 & 8 & 6 & 7 \\
Pendidikan formal ART wanita (thn) & 6 & 8 & 6 & 7 \\
Jumlah Tanggungan (orang) & 5 & 21 & 11 & 37 \\
Juml ART usia tidak produktif (pria)(orang) & 0 & 2 & 1 & 3 \\
Juml ART usia tidak produktif (wanita)(orang) & 0 & 5 & 0 & 5 \\
Juml ART usia produktif (pria) & 3 & 5 & 5 & 13 \\
Juml ART usia produktif (wanita)(orang) & 0 & 4 & 2 & 6 \\
\hline
\end{tabular}

\section{Pendapatan Rumah Tangga Petani}

Jika dilihat berdasarkan

kontribusi dan rata-rata pendapatan pada anggota rumah tangga kelompok tani Sabeulit mengacu pada Upah Minimum
Regional (UMR) Kabupaten Sumedang yang sebesar Rp 2.678.028,99 berdasarkan keputusan Gubernur Jawa Barat Tahun 2018, maka pendapatan per kapita rumah tangga petani teh masih rendah

Tabel 2 Kontribusi Pendapatan Masing-Masing Anggota Rumah Tangg TerhadapTotal Pendapatan Rumah Tangga (Rata-rata)

\begin{tabular}{lcccc}
\hline \multirow{1}{*}{ Pendapatan } & Lahan Sempit & Lahan Sedang & Lahan Luas & Total \\
& $\mathrm{Rp}$ & $\mathrm{Rp}$ & $\mathrm{Rp}$ & $\mathrm{Rp}$ \\
\hline Kepala Keluarga (KK) & 684.733 & 1.843 .333 & 2.151 .667 & 2.151 .667 \\
Anggota Rumah Tangga (ART) & 975.000 & 0 & 125.000 & 1.804 .356 \\
KK+ART & 1.659 .733 & 1.843 .333 & 2.276 .667 & 5.779 .733 \\
Pendapatan/kapita/bulan & 184.415 & 65.833 & 162.619 & 412,867 \\
\hline
\end{tabular}

\section{Ketersediaan Gabah Kering Giling}

Berdasarkan Tabel 3 didapat bahwa ketersediaan beras rumah tangga petani yang paling besar adalah strata lahan sedang kemudian diikuti oleh strata lahan luas, selanjutnya yang paling sedikit ratarata ketersediaan berasnya adalah rumah tangga strata lahan sempit.

Tabel 3. Rata-rata Ketersediaan Beras RT Petani Per Kapita Per Tahun menurut luas lahan

\begin{tabular}{ccccccccc}
\hline Ketersediaan Beras & \multicolumn{2}{c}{ Lahan Sempit } & \multicolumn{2}{c}{ Lahan Sedang } & \multicolumn{2}{c}{ Lahan Luas } & \multicolumn{2}{c}{ Total } \\
\cline { 2 - 9 }$(\mathrm{Kg})$ & $\mathrm{n}$ & $\%$ & $\mathrm{n}$ & $\%$ & $\mathrm{n}$ & $\%$ & $\mathrm{n}$ & $\%$ \\
\hline$>83$ & 2 & 66.7 & 4 & 66.7 & 3 & 100 & 9 & 75 \\
$1-83$ & 1 & 33.3 & 2 & 33.3 & & & 3 & 25 \\
Total & 3 & 100 & 6 & 100 & 3 & 100 & 12 & 100 \\
\hline
\end{tabular}


Pada daerah penelitian, masyarakat setempat khususnya rumah tangga petani teh, mempunyai kebiasan makan 3 (tiga) kali sehari. Frekuensi makan yang cukup tinggi ini memang dikarenakan aktivitas mereka cukup menghabiskan energi.

\section{Aksesibilitas}

Kombinasi antara ketersediaan makanan pokok dengan frekuensi makan (3 kali per hari disebut cukup makan, 2 kali disebut kurang makan, dan 1 kali disebut sangat kurang makan) sebagai Indikator stabilitas ketersediaan pangan yang dapat dilihat pada Tabel 4

Indikator ksebilitas/keterjangkauan dalam pengukuran ketahanan pangan di tingkat rumah tangga dilihat dari kemudahan rumah tangga memperoleh pangan yang diukur dari pemilikan lahan serta cara rumah tangga untuk memperoleh pangan. Akses yang diukur berdasarkan pemilikan lahan dikelompokkan dalam 2 (dua) kategori :

- Akses langsung (direct access), jika rumah tangga memiliki lahan sawah/lading.

- Akses tidak langsung (indirect access) jika rumah tangga tidak memiliki lahan sawah/ladang

Cara rumah tangga memperoleh pangan juga dikelompokkan dalam 2 (dua) kategori, yaitu :

- Produksi sendiri.

- Membeli.

Petani yang tegabung sebagai anggota Kelompok Tani Sabeulit tidak memiliki lahan garapan sehingga kategori langsung yang dimaksud adalah petani yang juga bekerja sebagai buruh tani padi kepada petani padi

Tabel 4. Rumah Tangga Petani Berdasarkan Aksesbilitas

\begin{tabular}{lccccccc}
\hline \multirow{2}{*}{ Pemililikan } & \multicolumn{3}{c}{ Cara Memperoleh Bahan Pangan } & & \multicolumn{2}{c}{ Total } \\
\cline { 2 - 5 } Sawah/ladang & \multicolumn{2}{c}{ Produksi Sendiri } & \multicolumn{2}{c}{ Membeli } & & \\
\cline { 2 - 5 } & $\mathrm{n}$ & $\%$ & $\mathrm{n}$ & $\%$ & $\mathrm{n}$ & $\%$ \\
\hline Punya & 7 & 100 & 3 & 60 & 10 & 83.3 \\
Tidak Punya & 0 & 0 & 2 & 40 & 2 & 16.7 \\
Total & 7 & 100 & 5 & 100 & 12 & 100 \\
\hline
\end{tabular}

\section{Kontinuitas}

Rumah tangga petani penggarap dikategorikan kurang kontinyu 23,1\% dari keseluruhan responden rumah tangga. Rumah tangga responden 76,9\% dinyatakan kontinyu stabilitas dan aksesbilitas ketahanan pangan komoditas beras sesuai data responden petani dalam memperoleh bahan pangan komoditas beras terkategori tidak stabil dalam pemenuhan > $83 \mathrm{~kg} / \mathrm{kap} / \mathrm{thn}$ dalam ketersediaan hal ini dikarenakan memiliki askes tidak langsung karena umumnya buruh tani lahan garapan teh starta sedang dan sempit tidak memiliki lahan sawah sehingga untuk mendapatkan beras dengan akses tidak langsung produksi sendiri dengan menambah pekerjaan sebagai buruh tani sawah, rumah tangga responden petani ini dinyatakan pada kategori kurang kontinyu dan, pada data sajian responden. Indikator kontinuitas ketersediaan pangan pada keseluruhan strata rumah tangga komoditas pangan beras dapat dilihat pada Tabel 5. Petani penggarap teh strata luas umumnya memiliki lahan sawah sehingga akses pangan komoditas beras termasuk ke dalam aksesbilitas langsung dan kontinyu. Petani penggarap teh strata luas menyimpan hasil produksi usahatani padi dalam bentuk gabah sebagai lumbung padi namun dijual langsung kepada tetangga sehingga ketersediaan untuk rumah tangganya tidak hanya produksi sendiri namun juga membeli ke pasar tradisional di Kota Sumedang sehingga masuk ke kategori aksesbilitas kontinyu. 
Tingkat kontinuitas ini mengartikan bahwa rumah tangga dapat memenuhi kebutuhan pokok hidupnya secara kontinyu atau setiap harinya dapat terjamin. Belum tentu suatu rumah tangga yang memiliki pendapatan besar dan memiliki ketersediaan pangan yang cukup dapat memenuhi kebutuhan hidupnya sehari-hari secara terus menerus jika tidak memiliki akses langsung terhadap pangan.
Rumah tangga yang berpendapatan besar dapat mengakses pangan dengan cara membeli, namun tidak menjamin hal ini dapat terjadi secara kontinyu karena adanya fluktuasi harga pangan. Tingginya harga pangan menjadi salah satu faktor penyebab daya beli rumah tangga terhadap pangan menurun sehingga kecukupan ketersediaan pangan pun menjadi terancam.

Tabel 5. Tingkat Kontinuitas Ketersediaan Pangan Rumah Tangga Petani Berdasarkan Strata Luas Lahan (\%)

\begin{tabular}{lcccccccc}
\hline $\begin{array}{c}\text { Tingkat } \\
\text { Kontinuitas }\end{array}$ & $\begin{array}{c}\text { Lahan } \\
\text { Sempit }\end{array}$ & $(\%)$ & $\begin{array}{c}\text { Lahan } \\
\text { Sedang }\end{array}$ & $(\%)$ & $\begin{array}{c}\text { Lahan } \\
\text { Luas }\end{array}$ & $\%$ & Total & $(\%)$ \\
\hline Kontinyu & 2 & 66.7 & 5 & 71.4 & 3 & 100 & 10 & 76.9 \\
Kurang Kontinyu & 1 & 33.3 & 2 & 28.6 & & 0 & 3 & 23.1 \\
TOTAL & 3 & 100 & 7 & 100 & 3 & 100 & 13 & 100 \\
\hline
\end{tabular}

\section{Kualitas}

Dalam penelitian ini, ukuran kualitas pangan hanya dilihat dari 'ada' atau 'tidak'nya bahan makanan yang mengandung protein hewani dan/atau nabati yang dikonsumsi dalam rumah tangga karena sulitnya menentukan ukuran kualitas pangan yang melibatkan berbagai macam jenis makanan dengan kandungan gizi yang berbeda-beda.

Secara keseluruhan, jika dilihat dari data pengeluaran untuk konsumsi makan (lauk-pauk) sehari-hari, rumah tangga petani teh di tempat penelitian memiliki pengeluaran untuk lauk-pauk berupa protein hewani dan nabati atau protein hewani saja. Bahkan sebagian besar rumah tangga pada semua strata hampir setiap hari mengkonsumsi tahu, tempe, dan ikan asin. Bagi mereka, masyarakat pedesaan ketiga jenis laukpauk tersebut seolah-olah menjadi makanan wajib pendamping nasi. Memang motif mereka mengkonsumsi lauk-pauk tersebut bukan karena pengetahuan gizi yang baik akan protein nabati ataupun protein hewani, namun lebih karena kebiasaan yang dilakukan secara terus menerus dan keterjangkauan daya beli mereka dalam mengakses pangan. Jika melihat acuan dari tim penelitian LIPI tentang jonsep dan ukuran ketahanan pangan rumah tangga di perdesaan, maka seluruh rumah tangga petani dapat dikatakan rumah tangga dengan kualitas pangan baik. Berikut adakah besaran pengeluaran protein hewani dan nabati rumah tangga petani dalam jangka waktu satu bulan dalam rupiah.

Tabel 6. Besaran Pengeluaran Protein Hewani dan Protein Nabati Berdasarkan Strata Luas Lahan (Rata-rata)

\begin{tabular}{lcccc}
\hline Pengeluaran Protein & Lahan Sempit & Lahan Sedang & Lahan Luas & Total \\
\hline Protein Hewani & 199,000 & 212,917 & 180,000 & 591,917 \\
Protein Nabati & 51,633 & 301,250 & 496,333 & 849,217 \\
Total & 250,633 & 514,167 & 676,333 & $1,441,133$ \\
\hline
\end{tabular}

Didapat bahwa secara keseluruhan pengeluaran untuk protein hewani pada semua strata luas lahan lebih besar dibandingkan dengan pengeluaran protein 
mereka lebih besar pula. Hal ini mengindikasikan bahwa dengan semakin besarnya pengeluaran protein suatu rumah tangga, maka semakin banyak kandungan protein yang dikonsumsi dan semakin baik kualitas pangan mereka. Jenis protein yang banyak dikonsumsi oleh Petani penggarap teh adalah ikan yang sudah diasinkan sebagai protein hewani dan hasil olahan kacang-kacangan seperti kacang polong, tempe, tahu dan kacang merah atau biasa disebut kacang edul oleh warga sekitar sebagai sumber protein nabati. Kosumsi daging ayam sangat jarang ditemui masih sering ditemui konsumsi telur ayam yang menurut Petani penggarap lebih terjangkau harganya, sedangkan konsumsi untuk daging sapi, daging domba ataupun daging kambing hampir tidak ditemukan.

\section{Indeks Ketahanan Pangan}

Indeks ketahanan pangan dihitung dengan cara mengkombinasikan keempat Indikator ketahanan pangan (ketersediaan beras, stabilitas ketersediaan, kontinuitas pangan dan kualitas pangan). Kombinasi antara kecukupan ketersediaan pangan dan frekuensi makan memberikan Indikator stabilitas ketersediaan pangan dengan akses terhadap pangan memberikan Indikator kontinuitas ketersediaan pangan. Terakhir indeks ketahanan pangan diukur berdasarkan gabungan antara Indikator kontinuitas ketersediaan pangan dengan kualitas pangan. Untuk indeks ketahanan pangan rumah tangga petani teh tersaji dalam Tabel 7.

Tabel 7 Indeks Ketahanan Pangan Rumah Tangga Petani Teh Menurut Strata Luas Lahan (\%)

\begin{tabular}{|c|c|c|c|c|c|c|c|c|}
\hline \multirow{3}{*}{ Akses Terhadap Pangan } & \multicolumn{8}{|c|}{ Stabilitas Ketersediaan Pangan Rumah Tangga } \\
\hline & \multicolumn{2}{|c|}{ Stabil } & \multicolumn{2}{|c|}{ Kurang Stabil } & \multicolumn{2}{|c|}{ Tidak Stabil } & \multicolumn{2}{|c|}{ Total } \\
\hline & $\mathrm{n}$ & $\%$ & $\mathrm{n}$ & $\%$ & $\mathrm{n}$ & $\%$ & $\mathrm{n}$ & $\%$ \\
\hline \multicolumn{9}{|c|}{ Total (sempit+sedang+luas) } \\
\hline Akses Langsung & 7 & 100 & 1 & 33.3 & & & 8 & 66.7 \\
\hline Akses Tidak Langsung & & & 2 & 66.7 & 2 & 100 & 4 & 33.3 \\
\hline Total & 7 & 58.3 & 3 & 25 & 2 & 16,7 & 12 & 100 \\
\hline \multicolumn{9}{|l|}{ Lahan Sempit } \\
\hline Akses Langsung & & & 1 & 100 & & & 1 & 33.3 \\
\hline Akses Tidak Langsung & & & & & 2 & 100 & 2 & 66,7 \\
\hline Total & & & 1 & 100 & 2 & 100 & 3 & 100 \\
\hline \multicolumn{9}{|l|}{ Lahan Sedang } \\
\hline Akses Langsung & 4 & 100 & & & & & 4 & 66.7 \\
\hline Akses Tidak Langsung & & & 2 & 100 & & & 2 & 33.3 \\
\hline Total & 4 & 100 & 2 & 100 & & & 6 & 100 \\
\hline \multicolumn{9}{|l|}{ Lahan Luas } \\
\hline $\begin{array}{l}\text { Akses Langsung } \\
\text { Akses Tidak Langsung }\end{array}$ & 3 & & & & & & 3 & 100 \\
\hline Total & 1 & 100 & & & & & 3 & 100 \\
\hline
\end{tabular}

Berdasarkan hasil tabulasi silang, maka rumah tangga dapat dibedakan menjadi tiga kategori, yaitu :

1. Rumah tangga tahan pangan

2. Rumah tangga kurang tahan pangan

Rumah tangga tidak tahan pangan adalah rumah tangga yang dicirikan oleh 4 hal, yaitu : a. Kontinuitas ketersediaan pangan kontinyu tetapi tidak memiliki pengeluaran untuk protein hewani maupun nabati.

b. Kontinuitas ketersediaan pangan kurang kontinyu dan hanya memiliki pengeluaran untuk protein 
hewani atau nabati, atau tidak untuk kedua-duanya

c. Kontinuitas ketersediaan pangan tidak kontinyu walaupun memiliki pengeluaran untuk protein hewani dan nabati.

d. Kontinuitas ketersediaan pangan tidak kontinyu dan hanya memiliki pengeluaran untuk protein nabati saja atau tidak untuk keduaduannya.

Karena bisa saja dengan besarnya pendapatan tersebut mereka tidak dapat mengelolanya dengan baik, sehingga stabilitas maupun kontinuitas ketersediaan pangan mereka tidak terpenuhi dengan baik.

Jadi, tingkat pendapatan dan pengeluaran yang terbentuk pada semua tingkatan strata rumah tangga ternyata tidak menjamin rumah tangga tersebut terkategori tahan pangan. Karena bisa saja dengan besarnya pendapatan tersebut mereka tidak dapat mengelolanya dengan baik, sehingga stabilitas maupun kontinuitas ketersediaan pangan mereka tidak terpenuhi dengan baik.

\section{KESIMPULAN DAN IMPLIKASI KEBIJAKAN}

Kesimpulan

1. Karakterisitik sosial ekonomi rumah tangga petani penggarap teh adalah:

a. Kepala keluarga semua strata ratarata berumur 51 tahun tergolong petani usia produktif. Rata-rata pendidikan formal kepala keluarga yang telah di tempuh yaitu selama 6 tahun atau lulusan sekolah dasar (SD).

b. Proporsi rumah tangga petani yang tergolong tahan pangan sebesar $58.3 \%$, rawan pangan $25 \%$ dan tidak tahan pangan $16.7 \%$ dari keseluruhan petani sampel.

\section{Implikasi Kebijakan}

\begin{tabular}{lccr}
\multicolumn{2}{c}{ Implikasi } & indikator & kajian \\
ketahanan & sebagai & gambaran & bagi \\
pemangku & kebijakan & khususnya & dan
\end{tabular}

pengetahuan bagi masyarakat sebagai bagian dari permasalahan yang dihadapi oleh manusia dalam pemenuhan kebutuhan pokok. Ketahanan pangan diukur berdasarkan aksesbilitas, ketersedian dan konsumsi berdasarkan pengeluaran rumah tangga terhadap pangan dan non pangan.

\section{Ucapan Terima Kasih}

Ucapan terima kasih kepada Kementrian Riset dan Teknologi yang sudah membiayai penelitian dalam DPRM tahun 2017 dan dilaksanakan tahun 2018. Terimakasih juga disampaikan kepada lembaga institusi Universitas Winaya Mukti yang telah mendukung baik moril ataupun materi sebagai lembaga tempat peneliti bernaung. Terimakasih kepada lembaga Dinas Pertanian dan Ketahanan Pangan, Badan Pusat Statistik (BPS) Jawa Barat sehingga tim peneliti mudah mendapatkan informasi dan data sekunder. Terakhir terimakasih kepada tim peneliti dan tim surveyor sehingga penelitian ini berjalan dengan lancer.

\section{DAFTAR PUSTAKA}

Badan Pusat Statistik. 2018. Pola Konsumsi Berdasarkan Rata-rata Pendapatann Per Kapita 201720178. BPS

Dinas Ketahanan Pangan Jawa Barat. 2018. Data Ketersediaan dan Konsumsi Beras di Jawa Barat.

FAO. 1996. World Food Summit, 13-17 November 1996. Rome, Italy: Food and Agriculture Organisation of the United Nations.

Hanani, Nuhfil. 2010. Pengertian Ketahanan Pangan. Fakultas Pertanian Universitas Brawijaya. Malang.

Hariyanto. 2009 Pola dan Intensitas Konversi Lahan Pertanian di Kota Semarang Tahun 2000-2009. Jurnal Vol 7, No. 1

PPK-LIPI. 2018. Ketahanan Pangan, Kemiskinan dan Demografi Rumah Tangga. Seri Penelitian PPK-LIPI 
No. 56/2004. Jakarta: Puslit kependudukan _ LIPI.

PPK-LIPI. 2018. Ketahanan Pangan, Kemiskinan dan Demografi Rumah Tangga. Seri Penelitian PPK-LIPI No. 56/2004. Jakarta: Puslit kependudukan _ LIPI.

Republik Indonesia. 2002. Peraturan Pemerintah Republik Indonesia Nomor 68 Tahun 2000 Tentang Ketahanan Pangan. Jakarta: Sekretaris Negara RI.

Ruswandi, Agus et. Al. 2007. Dampak Konversi Lahan Pertanian
Terhadap Kesejahteraan Petani dan Perkembangan Wilayah : Studi Kasus di Daerah Bandung Utara. Journal Agro Economic Vol. 25 No 022007.

Soemarno. 2010. Strategi Pemenuhan Kebutuhan Pangan Rumah Tangga Petani. Fakultas Pertanian. Universitas Brawijaya.

Tambunan, Tulus. 2010. Pembangunan Pertanian dan Ketahanan Pangan. Jakarta: Universitas Indonesia 